\title{
Difficulties and Countermeasures of College Students' Innovation and Entrepreneurship under the Background of "Internet Plus"
}

\author{
Zejiong Zhou', *, Qingting Zhan ${ }^{1}$ \\ ${ }^{1}$ School of Economics, Anhui University of Finance and Economics, Bengbu, Anhui, China \\ *aczzj123456@163.com
}

\begin{abstract}
The advent of the "Internet plus" era has brought a new round of major opportunities for the development of innovation and entrepreneurship. College students, as the youngest subject of innovation and entrepreneurship under the new situation, face many opportunities and challenges as well as opportunities. Firstly, this paper analyzes the current situation of college students' innovation and entrepreneurship from the aspects of policy orientation, college education and social environment. Secondly, it points out the main difficulties faced by college students' innovation and entrepreneurship. That is, the policy guarantee is insufficient, the innovation and entrepreneurship education system needs to be improved, and the social level lacks support. Finally, it puts forward corresponding optimization suggestions for the above three aspects, which provides a valuable reference for the development of college students' innovation and entrepreneurship.
\end{abstract}

Keywords: Internet plus, Innovation and entrepreneurship, Government policies, Innovation and entrepreneurship education, Social environment.

\section{Introduction}

Under the background of the rapid development of information technology, the Internet is profoundly changing the production and lifestyle of our whole society, and has also become an important driving force for today's economic and social development. Internet plus is formed in the process of deeply integrating Internet technology innovation results into all sectors of the economy and society. In March 2014, Premier Li Keqiang first put forward the concept of "Internet finance" in the government work report, and issued the call of "mass entrepreneurship and innovation" at the Davos Forum in the same year. In March 2015, "public entrepreneurship and innovation" appeared in the government work report. Premier Li Keqiang proposed that it should be one of the two engines of economic growth under the new normal. And the Internet plus action plan was put forward for the first time [1]. Crowd sourcing, the State Council issued the guidance on accelerating the construction of the public innovation platform for supporting the public in September of the same year, further clarified the important support significance of "Internet plus" for "mass entrepreneurship and innovation", and proposed that we should promote the sustained and healthy development of "crowd innovation ,crowd sourcing, crowd support and crowd financing", and strive to create a new pattern for innovation and entrepreneurship [2]. At this point, Internet plus has risen to the national strategic level, and the new era of innovation and entrepreneurship is coming. In this context, more and more college students participate in the wave of innovation and entrepreneurship and become the most dynamic main force of innovation and entrepreneurship.

Based on the current situation of the development of college students' innovation and entrepreneurship in China, this paper analyzes the main difficulties faced by college students' innovation and entrepreneurship under the background of "Internet +", and then puts forward corresponding countermeasures and suggestions, which plays a positive role in promoting the development of College students' innovation and entrepreneurship in China.

\section{Analysis on the Current Situation of College Students' Innovation and Entrepreneurship}

\subsection{Policy Orientation}

The policies related to college students' innovation and entrepreneurship can be traced back to the action plan for revitalizing education in the 21 st century issued by the Ministry of education in 1998. Since then, various supporting policies have been issued frequently for more than 20 years, and the focus of the policies is constantly changing with the sustainable development of economy and society. From the initial policy to the employment of university graduates, to the post crisis, the transformation of the university students into employment and entrepreneurship, and the improvement of various entrepreneurial preferences, and now the "Internet plus" era, the policy of innovation and entrepreneurship for college students has paid more attention to providing innovative and entrepreneurial services in a multi sectoral and comprehensive way, aiming at creating a good social environment for innovation and entrepreneurship [3]. By 2020 , the state has issued more than 400 documents on College students' innovation and entrepreneurship policies. From the number of policy texts and the increasing trend year by year, it can be seen that the state attaches importance to the cultivation of innovation and entrepreneurship talents, and the government has become an important driving force for College students' innovation and entrepreneurship.

\subsection{Higher Education}

With the support of the state, major universities are also constantly carrying out research and Exploration on innovation and entrepreneurship education. In 1999, the first national "Challenge Cup" College Students' Entrepreneurship 
plan competition was successfully held in Tsinghua University, which triggered a round of upsurge of innovation and entrepreneurship among colleges and universities across the country, which also means that the new concept of innovation and entrepreneurship education is gradually rising in China's colleges and universities. In 2002, the Ministry of education carried out the pilot work of entrepreneurship education in nine universities, including Tsinghua University, Renmin University of China and Shanghai Jiaotong University. China's higher education has gradually changed from spontaneous exploration to diversified development under the guidance of the government [4]. In June 2006, "Entrepreneurship China - National College Student Entrepreneurship Service Project" was fully launched under the joint organization of the Central Committee of the Communist Youth League and the all China Federation of students. Since then, major universities have responded and launched various initiatives of innovation and entrepreneurship education. Shanghai Jiaotong University has established the entrepreneurship college, which creatively uses the new model of "intangible college, tangible operation". Jiangnan University enables students to go out of the campus and experience the most real social entrepreneurship environment through the "Park boost" entrepreneurship education model. Tsinghua University, Central South University, Beijing University of technology and many other universities have also successively established entrepreneurship colleges, entrepreneurship centers or entrepreneurship research institutions. Colleges and universities in Zhejiang, Jiangxi and Guangdong have developed innovative and entrepreneurial practice activities such as "virtual entrepreneurship" and "business simulation" to enhance students' entrepreneurial ability and practical experience [5].

After continuous attempts, accumulation and summary, colleges and universities have explored distinctive innovation and entrepreneurship education modes based on their own school running characteristics, which can be roughly divided into the following six typical modes [6]: one is the comprehensive education mode represented by Tsinghua University and based on the school's innovation and entrepreneurship education, which provides training bases and guidance services for students' entrepreneurship. The second is the classroom leading model represented by Sichuan University, which focuses on curriculum, teaching, non-standard assessment and student evaluation. Third, the University of Electronic Science and technology, represented by the University of Electronic Science and technology, pays attention to the development of the industry and is committed to the discipline characteristic model of scientific and technological innovation and entrepreneurship. Fourth, the Wenzhou model, represented by Wenzhou University and combined with regional characteristics (such as Wenzhou entrepreneurial gene); Fifth, take Hangzhou Normal University as the representative, make full use of off campus resources and cultivate their own innovation and entrepreneurship advantages. Sixth, the "top innovative talent training mode" of the innovation and entrepreneurship practice class based on teaching students according to their aptitude and classified training.

\subsection{Social Environment}

In the era of Internet plus, people's way of thinking and lifestyle have undergone tremendous changes. The Internet has greatly satisfied people's access to a variety of information. We are willing to accept Internet products and services and pay for them. This trust and dependence on the Internet has laid a good social foundation for college students' innovation and entrepreneurship. In the new era, the positive social innovation and entrepreneurship atmosphere and the social and cultural environment advocating innovation and entrepreneurship have also played a certain role in promoting college students' entrepreneurship. Some studies have found that college students' entrepreneurs believe that the current social entrepreneurial atmosphere is relatively loose and have a high tolerance for innovation and entrepreneurship. Under this inclusive entrepreneurial environment, college students' entrepreneurs' self-confidence has been effectively improved, and they are more brave to start a business and take risks [7]. The relaxed social environment has undoubtedly stimulated the enthusiasm of College Students' entrepreneurs for innovation and entrepreneurship, encouraged them to have more courage to try new products and services, and had more opportunities to improve their enterprises.

At present, the "Internet plus" innovation and entrepreneurship situation of "government promoting entrepreneurship, market driven entrepreneurship, school boosting entrepreneurship, social support entrepreneurship and individual self starting business" has been formed in China. The transformation of university students' innovation and entrepreneurship achievements under the background of "Internet plus" has also achieved initial success, mainly in two aspects: on the one hand, the transformation of results in competition forms has achieved initial success. "Internet plus" high level competitions such as college students' innovation and entrepreneurship competition and entrepreneurship plan competition have become the arena and incubator for college students' innovation and entrepreneurship projects. The signing rate of award-winning projects has been continuously improved, and the marketization of project achievements faces more opportunities and choices, which has driven the effective connection between entrepreneurship projects and market investment. On the other hand, major colleges and universities have actively built platforms such as science and technology parks and entrepreneurship parks to promote production. The integration of education and education has promoted the organic connection of education chain, talent chain, industrial chain and innovation chain, and widened the channels for the transformation of college students' innovation and entrepreneurship achievements.

\section{The Dilemma of College Students' Innovation and Entrepreneurship under the Background of "Internet plus"}

Although China's college students' innovation and entrepreneurship has achieved remarkable results, due to their late start and limited development time, they will face some difficulties in the process of practice. If these problems are not solved in time, they will hinder the future stable development of college students' innovation and entrepreneurship.

\subsection{Insufficient Policy Guarantee}

In order to encourage college students to start their own businesses, the state has frequently issued documents for 
support, and governments at all levels have also issued a series of innovation and entrepreneurship policies and regulations. The introduction of relevant policies has indeed played a considerable role in promoting college students' innovation and entrepreneurship in the initial stage, but with the entrepreneurship entering the actual operation stage in the middle and later stage, various problems have gradually become prominent. Firstly, the government's support for college students' innovation and entrepreneurship is mostly reflected in various policy texts, which is lack of systematic planning and operability. College students are in a relatively weak position in the entrepreneurial market, and there are problems such as lack of social experience and insufficient management ability. Since a comprehensive and effective entrepreneurial service organization has not been established, many college students are facing the situation of entrepreneurial failure because they do not have a deep understanding of policies and lack of entrepreneurial orientation. Secondly, the preferential policies are not strong, but the procedures are complicated. Many of the government's support policies for college students' innovation and entrepreneurship seem to be very beneficial to college students' independent entrepreneurship, but there are many problems in the actual operation, such as high application conditions, less capital subsidies, complicated approval procedures and so on. Through the experience of some college students' innovative entrepreneurs, we can learn that the application procedures for some preferential projects are complex. For example, college students' entrepreneurs applying for loans are required to provide guarantees for two full financial allocation staff, which is difficult for most college students' entrepreneurs; There are many tax reduction and exemption projects that actually involve very little amount, some even only tens of yuan [8]. These preferential policies are of little practical use to college students who start a business for the first time, so it is difficult to achieve the expected purpose of the policy. Finally, policies have local differences. The innovation and entrepreneurship policies of all localities are gradually implemented in stages and levels under the overall guidance of the central policy and in combination with local characteristics. This inevitably leads to differences in the implementation of policies in different regions. Economically developed areas have sufficient material foundation and obvious policy tendency. They can pay attention to the cultivation of innovative talents in the early stage of the innovation and entrepreneurship chain, so as to lay a talent foundation for innovation and entrepreneurship. In the backward areas, the problem of resource supply is the first to be solved. Especially in some parts of China, the network infrastructure is still very backward, which is very unfavorable to the market promotion of the innovative and entrepreneurial college students who rely highly on the Internet plus technology and infrastructure. At the same time, the talent training in underdeveloped areas also lags behind, which will inevitably lead to problems such as difficult implementation of opportunities and resources supply, difficult implementation of policies in place and so on.

\subsection{Innovation and Entrepreneurship Education System Needs to Be Improved}

China's innovation and entrepreneurship education started late. Although colleges and universities promote the in-depth development of innovation and entrepreneurship education reform in many aspects such as organization, talent training system and innovation and entrepreneurship practice, the curriculum system and resource allocation are still in an immature stage. At this stage, when colleges and universities carry out innovation and entrepreneurship education, the education mode and teaching content tend to be single. All departments and majors in the school follow the same teaching plan, and there is a lack of personalized customized courses for students in different regions, different majors and different interest directions. Such "one size fits all" education obviously does not have practical effect, nor can it provide effective help for college students' Entrepreneurship in the future.

In addition, at present, there is a serious shortage of teachers majoring in innovation and entrepreneurship in Colleges and universities in China [9]. According to the statistics of the Ministry of education, there were more than 35000 full-time innovation and entrepreneurship teachers in Colleges and universities in China in 2021. Although the number of entrepreneurship and entrepreneurship mentors has increased rapidly, compared with the number of 41.83 million students and 9.09 million graduates, the number of teachers is obviously small, and the ratio of teachers and students is far lower than the requirement of 1:500. The shortage of teachers directly increases the teaching load of teachers. In this case, the teaching quality is difficult to be guaranteed. Therefore, although some colleges and universities vigorously carry out innovation and entrepreneurship education, the final effect is not ideal. At the same time, as the main body of innovation and entrepreneurship education teachers is school teachers, most of the teachers active in the front line of innovation and entrepreneurship education have two characteristics: they have neither systematically studied the theory of innovation and entrepreneurship education nor specific practical experience of innovation and Entrepreneurship Education [10]. This leads to the uneven quality of innovation and entrepreneurship teachers, and the weakness of the overall teachers has seriously restricted the in-depth development of innovation and entrepreneurship education in Colleges and universities.

\subsection{Lack of Support at the Social Level}

Although the state attaches great importance to the "Internet plus" innovation and Entrepreneurship of college students, because of the uncertainty and immaturity of the Internet plus as a new economic form, some investors or financing institutions look at the innovative and entrepreneurial opportunities of university students with suspicion, and even do not want to give them the opportunity. Secondly, college students are facing strong market competition pressure. Some large Internet enterprises rely on their own resources and platform advantages to carry out monopoly operation and reduce the entrepreneurial space of College students' entrepreneurs. Many college students' entrepreneurs face difficulties in resources, platforms and other aspects, often need the help of mature large enterprises, and finally become subsidiaries of these large enterprises [11]. At the same time, there are also some problems in the cultural atmosphere of innovation and entrepreneurship and the guidance of public opinion. Since entering globalization, China's society has been affected by diversification, and its social culture is in a complex state of openness mixed with utilitarianism. People are often eager for success, and the trend of "seeking speed" is rampant. Many people regard entrepreneurship as synonymous with success and pursue success in a short time. 
This wrong interpretation of success and entrepreneurship will inevitably mislead college students' entrepreneurs to a certain extent.

\section{New Ideas of Innovation and Entrepreneurship for College Students under the Background of "Internet plus"}

\subsection{Increase Government Support}

College students are faced with multiple difficulties and risks in the process of "Internet plus" innovation and entrepreneurship. Therefore, the support and guidance of the government is particularly important. Information infrastructure is one of the essential conditions for the development of "Internet plus". The government should further intensify the construction of information infrastructure in underdeveloped areas, provide basic support for Internet plus innovation and expand market, and stimulate the potential of innovation and entrepreneurship in less developed areas. In addition to infrastructure, policy support also needs to adjust measures to local conditions, fully consider the actual situation of various regions and universities, and accurately meet the needs of College students' entrepreneurs in combination with local unique advantages and resources [12]. College student entrepreneurs have different needs in different stages of innovation and entrepreneurship. Relevant policies should not only support the initial stage of entrepreneurship, but also ignore the cultivation period and growth period. It is suggested to introduce special laws and establish special institutions for college students' innovation and entrepreneurship, which can not only provide clear legal basis for relevant departments to implement policies, but also provide college students with the escort of perfect laws and regulations and the supervision and guidance of professional institutions, In the process of supervision, relevant institutions can timely find out the difficulties encountered by college students in innovation and entrepreneurship and give help. The central government and local governments should not only expand the policy coverage and financial support, but also simplify the examination and approval procedures to increase the support for college students' innovation and entrepreneurship. At present, the traditional planned economy thinking of emphasizing prior approval and neglecting supervision during and after the event still exists in many local governments, which leads to complex approval procedures and the same virtual supervision, which is very unfavorable to the development of college students' innovation and entrepreneurship. According to the idea of "relaxing access, strengthening management and optimizing services", government departments should formulate a mechanism to adapt to the development of college students' innovation and entrepreneurship and optimize the innovation and entrepreneurship environment.

\subsection{Establish A Scientific and Reasonable Innovation and Entrepreneurship Education System for College Students}

Innovation and entrepreneurship education should cover a wide range, be open to all students, establish a highly targeted and effective curriculum system, and teach according to students' majors, grades and cognitive levels. For example, different teaching models can be adopted according to different grades of students. For freshmen, the innovation and entrepreneurship course pays more attention to universal education and mainly teaches basic knowledge and necessary skills, which is intended to arouse students' interest in entrepreneurship. For sophomores and juniors, the innovation and entrepreneurship course is mainly an elective course, allowing interested students to choose to continue their study. The course content is set as entrepreneurship knowledge education and scientific thinking training, which is intended to stimulate the awareness of innovation and entrepreneurship. For students with strong entrepreneurial intention or graduating class students, targeted practical teaching can be carried out, with professional practice tutors providing oneto-one guidance, so that students can personally participate in entrepreneurial practice projects [13]. Teaching methods should get rid of modularization and simplification, adopt the integration of multiple methods (experiential, guiding, etc.), and encourage students to improve their ability in continuous thinking and practice.

As a highly comprehensive discipline, innovation and entrepreneurship education involves multi-disciplinary knowledge such as sociology, psychology, management and pedagogy. This requires innovation and entrepreneurship teachers not only to have a solid theoretical knowledge as a foundation, but also to have strong practical experience. As the backbone of the innovation and entrepreneurship education system, colleges and universities should pay attention to and strengthen its construction, and incorporate it into the long-term development plan of the University. On the one hand, colleges and universities should select a number of core backbone teachers as stable teaching teachers. At the same time, select some excellent young and middle-aged teachers to go deep into enterprises and scientific research institutes to experience the whole process of innovation and entrepreneurship, encourage them to participate in the "industry university research" project, truly feel the management and operation of enterprises, enrich practical experience in innovation and entrepreneurship and improve their practical ability. On the other hand, part-time tutors are an important supplement to the development of innovation and entrepreneurship education in Colleges and universities. Successful entrepreneurs can be invited as part-time teachers of innovation and entrepreneurship education. Compared with full-time teachers, they have obvious advantages of practical experience. They can use rich practical experience to guide college students to face various problems in innovation and entrepreneurship, which is often better than simple teaching. Therefore, in the construction of innovation and entrepreneurship teaching staff, colleges and universities can appropriately strengthen the construction of part-time tutor system in combination with their own characteristics, and adopt the division mode of "theory first, practice second" for full-time teachers and "practice first, theory second" for part-time tutors, so as to better promote the development of innovation and entrepreneurship education for college students [14].

\subsection{Optimize the Social Environment for Innovation and Entrepreneurship}

As a social action, college students' innovation and entrepreneurship is naturally inseparable from the influence of social environment. A good social entrepreneurship culture can stimulate college students' interest and motivation in 
innovation and entrepreneurship. Therefore, we should standardize the social entrepreneurship culture, form positive cultural values, and create a harmonious social environment for innovation and Entrepreneurship with the correct guidance of public opinion. This requires joint efforts of many parties: the government should strengthen the breadth and depth of innovation and entrepreneurship policy publicity, not only pay attention to the in-depth presentation and transmission of policy content and applicability, but also make use of the advantages of rapid communication and strong response of mass media to popularize publicity [15]. Enterprises should consciously improve their sense of social responsibility, treat the development of small and mediumsized start-ups with an objective attitude, and actively help and participate in the development of small and medium-sized enterprises; Colleges and universities should provide college students with an innovation and entrepreneurship practice platform. Through school enterprise cooperation, they can actively create a learning and practice platform, broaden the practice content, enrich the practice mode, provide practical opportunities for the achievement transformation of college Students' innovation and entrepreneurship projects, and improve the recognition of college students' entrepreneurs by enterprises in the process of practice. Through the linkage of government school enterprise system, we can truly create an efficient and benign social environment for innovation and entrepreneurship, and provide strong support for college students' entrepreneurs.

\section{Acknowledgments}

This work is supported by the project of Anhui University of Finance and economics undergraduate teaching quality and teaching reform project "construction and practice of innovation and entrepreneurship education system of national economic management major under the new economic management strategy" (Grant No: acjyzd2020017).

\section{References}

[1] Lv Hongling. Opportunities, challenges and countermeasures for college students to start their own business in the "Internet plus" era [J]. Journal of China University of Petroleum, 2017, 33 (01): 101-104.

[2] Guiding opinions of the State Council on accelerating the construction of mass entrepreneurship and innovation support platform [R]. Bulletin of the State Council of the people's Republic of China, 2015 (29): 7-12.

[3] Tan Yu, Li Mingxue, Wu Xiaowang. Research on the change and support of College Students' innovation and entrepreneurship policy based on the analysis of 59 college students' innovation and entrepreneurship policy texts [J]. Modern Educational Technology, 2019, 29 (05): 112-118.

[4] Qiao Mei. Opportunities and challenges of college students' innovation and entrepreneurship education under the background of "Internet plus" [J]. Education and Teaching Forum, 2016 (21): 1-3.

[5] Shen Zuyun. Let college students have the "third education passport" [N]. China Education Daily, 2011-03-30 (001).

[6] Wang Han. Research on the current situation and countermeasures of college students' innovation and entrepreneurship under the new economic situation $[\mathrm{J}]$. Theoretical Research and Practice of Innovation and Entrepreneurship, 2020, 3 (22): 194-195 + 198.

[7] Li Yue. Research on college students' innovation and entrepreneurship ecosystem [D]. Heilongjiang Academy of Social Sciences, 2019.

[8] Feng Ying, Zhang Zhuo. Analysis on the evolution and regional differences of innovation and entrepreneurship policies for college students in China based on the policy text from 1998 to 2019 [J]. Journal of the National Institute of Education Administration, 2021 (02): 52-60.

[9] Cao LuChen. Innovation of the education mode of innovation and entrepreneurship for college students under the perspective of "Internet plus" [J]. Journal of Hubei Vocational Opening University, 2021, 34 (17): 14-15.

[10] Zhou Qunhua. Research on optimization strategies for the construction of teaching staff of innovation and entrepreneurship education in colleges and universities [J]. Theoretical Research and Practice of Innovation and Entrepreneurship, 2021, 4 (01): 76-78.

[11] Shi Juan. Opportunities and challenges for college students to innovate and entrepreneurship under the "Internet plus" perspective [D]. Sichuan Normal University, 2017.

[12] Gu Yurong. Analysis of the external environment factors and countermeasures of college students' innovation and entrepreneurship in the Internet plus era [J]. Rural Economy and Technology, 2020, 31 (24): 273-275.

[13] $\mathrm{Hu}$ FangFang. Research on the innovation and entrepreneurship of university students under the background of "Internet plus" [D]. Henan University of Science and Technology, 2018.

[14] Zeng YangQiao, Wang Wei. The influence factors and countermeasures of college Students' innovation and entrepreneurship under the background of "Internet plus" [J]. China Market, 2021 (17): 175-176.

[15] Huang Xinping. Multi source flow analysis and improvement path research of college students' innovation and entrepreneurship policy in China [D]. Yunnan Normal University, 2021. 